Оригинални научни рад

347.56:338.3]:061.1EU(497.11)

doi:10.5937/zrpfns52-18018

Miloš B. Sekulić, Ph.D. Student

University of Novi Sad

Faculty of Law Novi Sad

milossekulic89@gmail.com

\title{
DEVELOPMENT RISKS - DEFINITION UNDER EUROPEAN UNION LAW AND JUSTIFICATION FOR IMPLEMENTATION IN SERBIAN LAW
}

\begin{abstract}
This paper analyses one of the most important and current issues related to the liability of the defective product producer, given that this form of liability has gained importance as a result of the development of consumer rights, the emphasis being on development risks as one of the bases for the exoneration of the producer as a responsible person. After a brief presentation of the liability of the producer of the defective product, the focus of the paper shifts to the institution of development risks, which is presented first from the aspect of the Directive on Liability for Defective Products in which it first appeared, while analysing the views of the European Court of Justice and all open issues thereof, as well as the recognition of its advantages and disadvantages. The final chapters of the paper examine whether development risks alter the legal nature of the producer's liability, i.e. whether they lead to the penetration of subjective elements into his traditionally objective liability, and analyse the justification for introducing this institution into the Serbian legislation, with the identified advantages and disadvantages.
\end{abstract}

Keywords: objective (strict) liability of the producer, defective product, unknowable defects, level of scientific and technical knowledge.

\section{INTRODUCTORY CONSIDERATIONS}

The liability of the defective product producer represents an important form of liability for damages in all legal systems. In theory, it is treated and has always been treated as an objective, i.e. strict type of liability, that is, liability irrespective 
of fault, the issue seemingly not being controversial. With the emergence of development risks as the bases for exculpation of the producer of defective product as responsible person from liability, the objective character of this type of liability became questionable. The essence of the problem is: Whether the inability of the producer to detect the defect of a product at the time of its release on the basis of the level of scientific and technical knowledge (development risks) should lead to his absolvent from liability and whether this introduces subjective elements into something previously considered in theory as purely objective liability?

The development risks had been defined in European Union law (hereinafter periodically also abbreviated as the EU law) in Council Directive 85/374/EEC of 25 July 1985 on the approximation of the laws, regulations and administrative provisions of the Member States relating to liability for defective products ${ }^{1}$, (hereinafter periodically also abbreviated as the Directive), which was amended and supplemented by the 1999 Directive $^{2}$, and thus found its way to the legal systems of almost all European countries.

The Serbian legislation does not recognize development risks, and whether it is justified to include them among the exculpatory grounds can be seen only after a detailed analysis of the purpose of their existence, as well as of the pros and cons that characterize them.

\section{LIABILITY OF THE PRODUCER OF DEFECTIVE PRODUCT}

As already stated at the outset, the liability of the defective product producer has been traditionally classified as objective (strict) liability, in the sense that it is the duty of that entity which has produced and placed on the market a product with deficiency that poses a greater risk of harm to man and the environment to be liable for the damage which such a product inflicts. Several persuasive arguments speak in favour of the producer's liability - he has received economic benefits from defective products, so it is logical for him to bare the harmful consequences in case they are inflicted by the product, furthermore the producer is most aware of the greater risk arising from the product's deficiency, as he is most familiar with the properties of the product, etc.

${ }^{1}$ Council Directive 85/374/EEC of 25th July 1985 on the approximation of the laws, regulations and administrative provisions of the Member States concerning liability for defective products, Official Journal of the European Communities, L 210 Volume 28/1985.

2 Directive 1999/34/EC of the European Parliament and of the Council of 10 May 1999 amending Council Directive 85/374/EEC of 25th July 1985 on the approximation of the laws, regulations and administrative provisions of the Member States concerning liability for defective products, Official Journal of the European Communities, L 141 Volume 20/1999. 
Historically, this type of liability has gained in importance with the rise of mass consumption products, because these may dispense mass, serial damage to a large number of persons. In the first place, these are industrial products, but this does not necessarily need to be the case, since the producer always has strict liability regardless of wrongdoing, even in case he had produced a craftsmanship product or a unique product.

The thing that triggered a far-reaching reaction of legal experts and the regulation of this kind of liability on the European level was the emergence of a drug called thalidomide which was used by the pregnant women during the 1970s, which, as it later turned out, had side effects that led to the birth of thousands of children with deformities. ${ }^{3}$ In order for this not to happen again, the European Convention on Product Liability in regard to Personal Injury and Death ${ }^{4}$ was adopted in 1977 within the Council of Europe's framework. As a predecessor of the aforementioned Directive, it imposed an obligation for the Member States of the today's European Union (hereinafter periodically also abbreviated as the EU) to implement it in its national legislation and prescribe the producer's liability, because of which it nowadays represents one of the pillars on which the EU consumer law stands. ${ }^{5}$

The Directive removed the differences in the national legislations of the EU Member States with regard to the nature of the producer's liability by prescribing this liability as objective one. Up until then, national legislation generally provided for the subjective liability of the producer, whilst this liability was objective, i.e. strict in France, Belgium and Luxembourg. The Legal Affairs Committee was of the view that the introduction of objective liability protects consumers, and that the producer is in the best position to know whether a product on the market has a defect because he has the easiest access to information, and can also calculate the price of the product so that it exceeds the high costs of the insurance premium against the damage that such a product might cause. ${ }^{6}$

${ }^{3}$ See: Maria Karanikić Mirić, Objektivna odgovornost za štetu (Strict liability for damages), Belgrade 2013, pp. 191-192.

${ }^{4}$ European Convention on Products Liability in regard to Personal Injury and Death, European Treaty Series, No. 91/1977.

${ }^{5}$ The Directive was adopted with the aim of eliminating the noticed differences in the domestic laws of the Member States of the EU, which led to distortions in relation to competition and negatively affected the freedom of movement of goods in the common market, another reason for its adoption being the need for homogenous legal regime of protection of aggrieved consumers. For more about this see: Petar Đundić, Harmonizacija pravila o odgovornosti proizvođača u državama članicama EU i najvažnije odredbe Direktive o odgovornosti za proizvode sa nedostatkom (85/385/ EC) (Harmonization of the Rules on Producer's Liability in the EU Member States and the Most Important Provisions of the Directive on Liability for Defective Products (85/385/EC)), Zbornik radova Pravnog fakulteta u Novom Sadu (Proceedings of Novi Sad Faculty of Law) 2/2009, p. 459.

${ }^{6}$ Lori M. Linger, The Products Liability Directive: A Mandatory Development Risks Defence, Fordham International Law Journal Volume 14 2/1990, pp. 483-484. 
The term product in the Directive encompasses movable items, including those that are incorporated into other movable or immovable property, as well as electricity. According to the solution from the Directive, the product has a defect if it does not provide the appropriate security expected by others, taking into account all the circumstances of the case, and in particular the advertisement, the normal use of the product and the time when the product was put into circulation. It is explicitly stipulated that it will not be considered that the product is defective if subsequently a better product is released into circulation. ${ }^{8}$ Therefore, the Directive has defined the concept of defect, which is essential for the liability of the producer under discussion here, in a generic manner, without any classifications that could be carried out. ${ }^{9}$

In the first place, the Directive envisages the liability of the producer, which it recognizes in the producer of a final product, raw material or component, as well as the person who, by placing his name, brand name or any other distinctive characteristic, designates himself as the producer. The producer is also equated with the importer of products for the territory of the European Union if he imported the products as part of his regular business activity, and lastly, there is the seller's liability, if the product does not indicate who the producer is and the seller did not inform the injured party about his identity within a reasonable time, as well as in case when it is not known who is the importer of a product, regardless of whether the producer is designated or not. ${ }^{10}$

${ }^{7}$ Art. 2. of the Directive.
${ }^{8}$ Art. 6. of the Directive.

${ }^{9}$ In theory, there is a division into structural defects, production shortcomings, and lack of information. "Structural defects are the dangerous properties of products that arise at the level of conceptual and technological design of the product concept and the way of its production, and are necessarily found in each individual product of the series produced according to such a plan. The shortcomings in production exist when a particular product is different from other products in the series in which there is no structural defect, that is, when a particular product does not meet the standards of the series and because of this deviation presents an increased risk. Deviations in the production process can arise from any cause (human error, machine malfunction, defect in raw materials, etc.), but also when the manufacturer has acted with all necessary attention.” The shortcomings in the notification would be the failure of the manufacturer to pre-empt the occurrence of damage, which he could have predicted, from the regular hazardous properties of things, by informing consumers about safe ways to use the product or on possible dangers in certain ways of using it. For more on this see: Silvija Petrić, Maja Bukovac Puvača, Problem razvojnih rizika kod odgovornosti za neispravan proizvod (The Problem of Development Risks in Liability for a Defective Product), Zbornik radova međunarodnog savjetovanja „Aktualnosti građanskog i trgovačkog zakonodavstva i pravne prakse" (Proceedings of the International Consultation "Current Affairs of Civil and Commercial Legislation and Legal Practices") Neum 1/2008, p. 211. In the United States, the Restatement of Law (Third) - Torts, adopted by the American Law Institute in 1998 instituted a division into defects in the production process, for which the manufacturer is liable irrespective of his guilt, defects in terms of product design and warning defects, for which the manufacturer is liable on basis of his fault. For more on this see: P. Đundić, pp. 463-464.

${ }^{10}$ Art. 3. of the Directive. 
The producer, as well as the importer and seller, shall be liable for damage to the injured person due to death or personal injury, as well as for property damage, whereby the Directive requires that the injured party had used the destroyed or damaged product for private purposes or consumption and that the damaged product was generally intended for such use and consumption. With regard to property damage, the Directive provides for a census of EUR 500. ${ }^{11}$

In terms of Serbian law, it is first necessary to say that Zakon o obligacionim odnosima $^{12}$ (the Law of Contracts and Torts, hereinafter periodically also abbreviated as ZOO) was the first regulation in Europe that regulated the liability of the producer of a defective thing, in the section dealing with objective liability. The ZOO's provisions are, however, very scarce in terms of this matter, so it contains only two rules. The first rule is taken from the Mihailo Konstatinovićs Skica za zakonik o obligacijama i ugovorima ${ }^{13}$ (Sketch for the Code of Obligations and Contracts), and prescribes that if the producer did not know about the defect of things he produced and put into circulation, and which defect represents a risk of harm to persons or things, he will be liable for the damage that could arise as a result of this deficiency, regardless of his guilt. According to the second rule, incorporated into the ZOO under the influence of the United States case-law ${ }^{14}$, if the producer has not taken all necessary measures to prevent damage which was foreseeable by him, either by warning, safe packaging or other appropriate measure, he is also liable for the dangerous properties of the thing. ${ }^{15}$

There are certain controversies in relation to the second rule. Firstly, it is arguable whether this is a matter of liability of the producer of a thing with a defect in the true sense of the word, and it should be noted that the producer in this instance is responsible for the dangerous properties of things that do not make the thing defective, that is, they do not represent its defect. ${ }^{16}$ The nature of this liability is also arguable, and some authors consider it to be subjective in character and that the grounds for the liability of the manufacturer lay in his guilt ${ }^{17}$, while others

${ }^{11}$ Art. 9. of the Directive.

12 Zakon o obligacionim odnosima, Sl. list SFRJ, br. 29/78, 39/85, 45/89 - odluka USJ i 57/89, Sl. list SRJ, br. 31/93 i Sl. list SCG, br. 1/2003 - Ustavna povelja (the Law of Contracts and Torts, Official Gazette of the SFRY, no. 29/78, 39/85, 45/89 - Decision of the Yugoslav Constitutional Court and 57/89, Off. Gazette of FRY, no. 31/93 and Off. Gazette of SMne, no. 1/2003 - Constitutional Charter).

${ }^{13}$ See: Katarina Ivančević, Građanskopravna odgovornost proizvođača za štetu od neispravnog proizvoda (Civil Liability of the Producer for Damage Inflicted by the Defecive Product), Pravni zapisi (Legal Records) 2/2012, p. 324.

${ }^{14}$ Ibid., p. 324.

${ }^{15}$ Art. 179. of the ZOO.

${ }^{16}$ See. M. Karanikić Mirić (2013), p. 192.

${ }^{17}$ Jožef Salma, Obligaciono pravo (Contracts and Torts Law), Novi Sad 2009, p. 596. 
are of the opinion that the liability of the producer is in this case a strict (objective) one and that he can be relieved of liability only if he proves that he acted in line with an objective and very high set of standards of behaviour. ${ }^{18}$

What is undisputed is that the ZOO has become obsolete in terms of its provisions on liability and leaves many questions unanswered. The ZOO does not prescribe what is considered as a product, all the more - it uses the term thing, which means that the producer is also liable for the defects of real estate ${ }^{19}$, which is not something that is usually seen in comparative legislation, and it does not exist in the Directive. Lastly the ZOO does not define when the thing has a defect, from which moment there is a liability of the producer, etc.

Liability of the producer, as envisaged by the ZOO, is an example of noncontractual liability, therefore it is not necessary that the producer and the injured party enter into a contract before the occurrence of the damage. Any person who has suffered damage caused by the defected product may ask the producer for compensation. On this basis, this type of liability should be distinguished from the liability of the seller for material defects of things and the liability of the producer and the seller on the basis of the guarantee for the proper functioning of technical products prescribed by the ZOO, because the said cases fall within the domain of contractual liability.

Serbian consumer protection legislation was novelised with the adoption of the Zakon o zaštiti potrošača ${ }^{20}$ (Consumer Protection Act, hereinafter periodically also abbreviated as ZZP), which is exclusively applicable when the producer of the defective product is at the same time the trader (a legal or natural person who appears on the market in the scope of its business activity or for other commercial purposes, incl. other persons who operate in his name or on his behalf), then it is necessary that the damage is inflicted on the consumer (a physical person who has procured goods or solicited services on the market, for the purpose other than its business or other commercial activity), and lastly that there is property damage as a result of death or injury or that the issue involves destruction or damage to the property which the affected party has usually used for personal use or consumption..$^{21}$ In all other cases, under the Serbian law, the provisions of ZOO are applicable in relation to liability, which means that this regulation covers all other issues with regard to the liability of the producer, it also allows the legal entity to obtain the capacity of the injured party, regulates non-pecuniary damages, etc.

${ }^{18}$ See: M. Karanikić Mirić (2013), p. 193.

${ }^{19}$ See: K. Ivančević, p. 334.

${ }^{20}$ Zakon o zaštiti potrošača, Sl. glasnik RS, br. 62/2014 i 6/2016 - dr. zakon (Consumer Protection Act, Off. Gazette of RS, no. 62/2014 and 6/2016 - new legislative act).

${ }^{21}$ Art. 5. of the ZPP. 


\section{ON DEVELOPMENT RISKS IN GENERAL}

Art. 7. para. 1. of the Directive prescribes when it is that the producer is relieved of liability, and those are the following cases: if he proves that he did not place the product into circulation, if he shows it is probable that the defect did not exist at the time of placing of the product on the market, if he proves that the product was not designated for sale or other business purposes nor that it has been produced and placed on the market in the course of his business, if he proves that the product's defect is the result of compliance with enforceable regulations, if he proves that the state of scientific and technical knowledge at the time of placing the product on the market was not such that enabled the product's defect to be discovered, and the component producer is relieved of liability and if he proves that the damage is caused by the construction of the main product or by the producer's instructions of use for the main product. ${ }^{22}$ In addition, the producer shall be relieved of liability if he proves that the damage is caused solely by the action of the injured party or the person for whom he is responsible, and by the action of a third party, which the manufacturer could not foresee or the consequences of which could not have been avoided or remedied..$^{23}$

Of all the above-mentioned exculpatory reasons, the most attention is drawn to the "the state of scientific and technical knowledge at the time when he [the producer - Ed.] put the product into circulation was not such as to enable the existence of the defect to be discovered", as stated in Art. 7. para. 1. point (e) of the Directive. This basis for relieving the producer of liability is called "development risks".

${ }^{22}$ The fact that the Directive is not just a legal act that creates a formal obligation for states to implement its solutions in their national legislation, but rather that it represents a legal act of truly high-quality content, can be concluded since the solutions from the Directive represent inspiration to other norm-makers. Thus, numerous development projects for the harmonization of civil law in the EU follow and take over the rules of the Directive. In this regard, it is worthwhile to point out that this is the case with the Draft Common Frame of Reference, which, in particular with regard to manufacturer's liability, envisages in Art. VI-3: 204. The same list of grounds for the exemption from liability as the one prescribed by the Directive, including development risks. On the creators of the Draft, its academic character, structure, role models in the course of its adoption and reactions of the expert public, see: http://hwb-eup2009.mpipriv.de/index.php/Study_ Group_on_a_European_Civil_Code, 15 February 2018, https://www.asil.org/eisil/study-groupeuropean-civil-code, 01 June 2018 , https: //www.gbz.hu-berlin.de/research/projects/existing-ecprivate-law, 01 June 2018, Atila Dudaš, Od Načela evropskog ugovornog prava do Nacrta okvirnih pravila (From the Principles of European Contract Law to the Draft of the Framework Rules), Anali Pravnog fakulteta u Beogradu (Annals of the Faculty of Law in Belgrade) 1/2012, pp. 329334, and for an alternative translation see: Dušanka Đurđev, Nacrt zajedničkog referentnog okvira za evropsko provatno pravo iz 2009. godine (Draft Common Frame of Reference from year 2009), Zbornik radova Pravnog fakulteta u Novom Sadu (Proceedings of Novi Sad Faculty of Law) 2/2010, pp. 65-82.

${ }^{23}$ Art. 8. of the Directive. 
Development risks could be defined as defects of products that were discovered after placing the product on the market, which at the time of product marketization could not have been detected because the state of science and technology was not at the level that allowed it. Science and technology are evolving, it is natural that human knowledge is growing in time, and in some cases it allows for the product's deficiency to be uncovered subsequently after the product has already been put into circulation and after the damage has been caused. In other words, development risks are defects of products that were not available to human knowledge at the time of placing of the products on the market, that is, they were still inconceivable at that time.

In relation to development risks, it is necessary to explain some other things as well. Namely, development risks are called "objectively" inconceivable defects. This inconceivableness in the objective sense indicates that the exclusion of the producer's liability does not depend on whether, according to his subjective properties, he could notice a product shortcoming at the time it was placed on the market. In other words, the conduct and behaviour of the producer in any particular situation does not play any role in terms of his success in case of referring to development risks. It is important that the product's defect could not have been determined objectively, taking into account the level of scientific and technical knowledge, regardless of whether there was reasonableness in the behaviour of the producer, whether the producer could, in accordance with his knowledge and abilities, see such a defect. Therefore, the product deficiency (in)comprehensibility test is purely objective, it is also set forth in Art. 7. para. 1. point. (e) of the Directive, and all subjective elements must be set aside. However, objectivity in terms of incomprehensibility of product defects should not be viewed in the absolute sense, because "the truth is that any defect can be discovered prior to marketing given sufficient testing. Such testing simply requires time and money." ${ }^{4}$ It is not realistic to require the producer to test the products to the final limits before placing them on the market. Such tests should be carried out mainly on people in real life situations, which would require a lot of time and money. If tests were carried out before all potential risks that could arise from the use of the product were eliminated, such a test could be affordable to only an extremely small number of producers, and the consumers would suffer the damage as research would stagnate and science and technology would not develop at sufficient pace to enable them to achieve a significant benefit from it. ${ }^{25}$ The conclusion is that the absolute objective discoverability of the product's defect cannot be expected, and therefore it should not be strived toward. When it is said that the defect of a product is objectively undiscoverable, then it should be considered that it cannot be detec-

${ }^{24}$ Christopher Hodges, Development Risks: Unanswered Questions, The Modern Law Review Vol. 61 4/1998, p. 568.

${ }^{25}$ Ibid., p. 561. 
ted by the highest scientific and technical knowledge at a given moment. Such knowledge must be more than acceptable; it should be in all respects satisfactory to the reasonable amount of testing that has been carried out.

It is evident from the above said that the (un)discoverability of the defect of a product is correlative to the appropriate scientific and technical knowledge at the time of placing the product into circulation or its marketization. Without understanding what scientific and technical know-how represents, it cannot be examined whether the producer should be relieved of responsibility when referring to development risks, which is precisely what makes this a big problem, because scientific and technical knowledge can hardly be uniformly understood. Simply put, it is understood as a multitude of facts, hypotheses and opinions of a great number of scientists and experts. Scientific and technical knowledge is dynamic, it is in constant development and is continually changing. ${ }^{26}$ When we take into account the extremely rapid advances in science and technology, and the growing involvement of developing countries in research processes, then the question arises as to whether the facts, results, and in particular opinions, estimates and sketches can in any way be reduced to an assortment that would represent the scientific and technical knowledge of the human race. What can be done when researchers and scientists do not agree on the solution of a particular problem, when there is no consensus on what scientific and technical knowledge is? How to set aside the dynamism of scientific and technical knowledge and limit it to only one single moment of putting the product into circulation? In the light of these issues, it seems that no regulation, including the Directive in question, can provide a satisfactory solution. It would be significant if some case-law could set certain guidelines, but at the moment it is still scarce, and in such circumstances, what remains is the examination of the circumstances of each particular case, then the rational consideration of the problem and the acceptance of the inability to elevate the scientific and technical knowledge to the level of "scientific and technical omniscience."

The Directive envisaged development risks as the basis for releasing the producer from liability, this causing important implications in the distribution of the risk of damage caused by a defective product. The question to which the Directive provides an answer is: Is the risk of a subsequent, belated knowledge of the product's defect on the part of the producer or on the consumer's side? Since the Directive has adopted development risks as the basis for releasing the producer from liability, this means that development risks are the burden of consumers, and that the consumer is the one at risk of changes in human knowledge from the time of product marketization to the occurrence of a harmful effect. ${ }^{27}$ On the other

${ }^{26}$ Ibid., p. 566.

${ }^{27}$ See: Marija Karanikić, Odgovornost za razvojne rizike (Liability for Development Risks), Anali Pravnog fakulteta u Beogradu (Annals of the Faculty of Law in Belgrade) 2/2005, p. 169. 
hand, development risks open the way for the producer to avoid liability if he proves that the level of scientific and technical knowledge at the time of product marketization was not such that the deficiency could then be detected. In light of the said, what is most evident from the outlaid is that the Directive deviates from the principle of maximum protection of consumers by introducing development risks, but this is only one of the problems that development risks create.

Given the implications which come with the introduction of development risks, first of all in terms of risk allocation contrary to the interests of consumers, it is clear that the introduction of the ability to relieve the producer of liability by referring to development risks from its beginning was a controversial rule. In fact, the first draft text of the Directive written in 1974 not only did not anticipate the defence of the manufacturer based on development risks, but explicitly prevented it. It was considered that the existence of development risks would lead to the situation that in each case the damage from unknowable defect is borne by each affected consumer individually, and it was suggested that it is only desirable to accept the objective (strict) liability of the producer and thus enable the producer to distribute the burden of harmful effects to a large number of consumers. However, the proposed solution was not acceptable to all parties that participated in the adoption of the Directive, and in particular the United Kingdom insisted on protecting consumers through development risks. As the unanimity of the Member State of the EU votes was necessary in order to reach a decision, the development risks in the final, adopted text of the Directive were nonetheless included as exculpatory reasons, ${ }^{28}$ but they did not cease to be the topic of debate. At the time of the adoption of the Directive, the consumer lobby also had a major influence, and despite the acceptance of development risks as the basis for releasing the producer from liability, a compromise solution was introduced in the sense that it was ultimately for the Member States of the EU to decide whether they will follow the Directive or not, in terms of solutions envisaging development risks. ${ }^{29}$

Art. 15. para. 1. point (b) of the Directive leaves the possibility for the Member States to prescribe by their national legislation that the producer will be liable even if the level of scientific and technical knowledge at the time of product marketization was not such as to enable the product's defect to be identified, the Directive thus leaving it to the discretion of Member States to exclude the existence of development risks. This solution seems somewhat illogical. Although Member States have been given the possibility of deviation primarily to comply with existing, applicable national legislation, it appears that the Directive makes a step backward with this provision. Its purpose is precisely the harmonization of the

\footnotetext{
${ }^{28}$ See: S Petrić, M. Bukovac Puvača, p. 214.

${ }^{29}$ See: C. Hodges, p. 563.
} 
legislation of Member States, ${ }^{30}$ but if the Member States are left with the freedom to exclude development risks, then this undermines the objective that the Directive intends to achieve and the desired harmonization cannot be fully realized. ${ }^{31}$

\section{DEVELOPMENT RISKS IN THE EU MEMBER STATES AND IN THE PRACTICE OF THE EUROPEAN COURT OF JUSTICE}

Incorporating the Directive into the national legislations of the EU Member States was a slow process, but ultimately a successful one. In terms of development risks, as the basis for releasing the producer from liability, most Member States have accepted the solution from the Directive and thus placed development risks on the list of exculpatory reasons. The only Member States that have exercised the right envisaged under Art. 15. para. 1. point. (b) of the Directive are Finland and Luxembourg, and in these countries the producer bears the burden of development risks. However, the situation is only seemingly straightforward in some important Member States whose legislation is considered to be a model for others, so significant restrictions exist in Austrian, Spanish, German and French law.

In Austria, the Supreme Court ruled that development risks could lead to the exemption of the producer from liability only if the defect was discovered by an expert appointed by the court, by a series of tests and inspections, and that the defect was not known to the experts prior to initiating the proceedings before the court and placing the product on the market. ${ }^{32}$

The Spanish lawmaker has limited the producer in the sense that he can be relieved of his responsibility only through productive risks when it comes to certain types of products. However, the most important products from the product range, food and pharmaceutical products, were left out, so the defects in them cannot be justified by the inadequate state of scientific and technological knowledge at the time of placing these products on the market.

A similar situation is also envisaged in German legislation, that does not allow the producer to be relieved of liability when it comes to defects that occur in pharmaceutical products and genetically engineered products. ${ }^{33}$ In addition

${ }^{30}$ On the extent to which the national legislation has been harmonized through the validity of the Directive see: P. Đundić, pp. 470-472.

${ }^{31}$ See: L. M. Linger, p. 485.

${ }^{32}$ Report from the Commission to the European Parliament, the Council and the European Economic and Social Committee, Fourth report on the application of Council Directive 85/374/ EEC of 25 July 1985 on the approximation of laws, regulations and administrative provisions of the Member States concerning liability for defective products amended by Directive 1999/34/EC of the European Parliament and of the Council of 10 May 1999, Brussels 2011, https://eur-lex.europa.eu/legal-content/EN/TXT/PDF/?uri=CELEX:52011DC0547\&from=EN, 01 June 2018.

${ }^{33}$ Cited in line with: M. Karanikić (2005), p. 171. 
to legislative restrictions, the German courts have also made their contribution to aggravating the producer's position due to the fact that, according to their interpretation, the legal provision on the exemption of producer from liability based on development risks relates solely to defects in the construction and design of products. Accordingly, the producer cannot be relieved from liability if the defect has occurred in the production of a particular piece of product, but only if it is a defect that exists throughout the production line. ${ }^{34}$

In France, the producer is liable for the defect of which he could not have been aware of, only when the damage arose from products obtained from the human body and products marketed before 1998, when France implemented the provisions of the Directive into its legal system. In France, there had previously been a ten-year deadline during which the producer was obliged to monitor the product he had placed on the market, and only the one who carried out this obligation could successfully refer to development risks. Such a rule has ceased to be valid after the European Court of Justice found that it is not in line with EU law. ${ }^{35}$

The United Kingdom represents a special case, since it introduced into its legal system a modified rule on development risks from the Directive and thus opened some issues that needed to be addressed. The Consumer Protection Act 1987, in Art. 4. para. 1. point (e) states that "the producer of a defective product may be relieved of liability for damages from such a product if he proves that the state of scientific and technical knowledge at the relevant time was not such that a producer of products of the same description as the product in question might be expected to have discovered the defect if it had existed in his products while they were under his control". ${ }^{36}$ It is obvious that the problem in this version of development risk rules is the introduction of a category of "producers of the same kind of products", that is, introducing, at first glance, subjective elements in the form of the expected, reasonable treatment of such a producer in the same situation as the specific producer whose liability is being examined.

For these reasons, the European Commission (hereinafter also referred to as the Commission) has launched proceedings against the United Kingdom before the European Court of Justice (hereinafter also referred to as the Court) to examine whether the United Kingdom's domestic law in question is compatible with law (Commission v. United Kingdom). The European Commission's argument was that the test referred to in Art. 7. para. 1. point (e) of the Directive is an objective one, i.e. that the Directive requires the producer to prove the objective inability to detect the defect of the product according to the "general degree of scientific and technical knowledge" and that the United Kingdom, by its rule, subjected the

\footnotetext{
${ }^{34}$ Ibid., p. 187.

${ }^{35}$ Cited in line with: S. Petrić, M. Bukovac Puvača, p. 215.

${ }^{36}$ Ibid., p. 219.
} 
producer's behaviour to a test of reasonableness, which implies the introduction of his subjective liability. On the other hand, the United Kingdom pointed out that the test in its domestic law is identical to the test set out in the Directive and that they are both objective inasmuch that it is not questioned what a specific producer could know but what kind of knowledge is expected from the producer belonging to the same type of entity as that producer whose liability is being investigated. They stated that Art. 7. para. 1. point (e) of the Directive should not be interpreted strictly, because then the defence of development risks is not enforceable in practice, but that an objectively usable standard is required, which is the standard of careful behaviour of entities belonging to the same type of producers. ${ }^{37}$

The Court's Judgement ${ }^{38}$ rejected the claim of the Commission, finding that there was no conflict between provision of the United Kingdom's domestic law and Art. 7. para. 1. point (e) of the Directive. In addition to this general point of view, the Court has taken some others stances, which are of relevance for a better understanding of development risk issues.

Thus, in its Judgement, the Court first gave an explanation of scientific and technical knowledge, saying that this notion "is not specifically directed at the practices and safety standards in use in the industrial sector in which the producer is operating, but, unreservedly, at the state of scientific and technical knowledge, including the most advanced level of such knowledge, at the time when the product in question was put into circulation." 39 The Court further noted that "the state of knowledge of which the producer in question actually or subjectively was or could have been apprised, but the objective state of scientific and technical knowledge of which the producer is presumed to have been informed." ${ }^{\prime 4}$ In accordance with the stated, the Court insists on the totality of scientific and technical knowledge and objective character test under Art. 7. para. 1. point (e) of the Directive. By doing this, this Judgement confirms the previous theoretical considerations and makes it unambiguous that even after the establishment of the institution of development risks, the producer's liability remains objective, i.e. strict, which means that he cannot be relieved of liability if he proves that he is not guilty of not being able to know that the product is defective in the time when it was put into circulation, because the level of scientific and technical knowledge at the time did not give him the opportunity to detect it. However, the Court failed to establish that a provision in the law of the United Kingdom is incompatible with

${ }^{37}$ Ibid., p. 219.

${ }^{38}$ Case-300/95, Commission v. United Kingdom, Judgement of The Court (Fifth Chamber) 29 May 1997, http://curia.europa.eu/juris/showPdf.jsf;jsessionid=9ea7d0f130da3fb411dee487471 ba916ba097db5a792.e34KaxiLc3eQc40LaxqMbN4Pb3iPe0?text=\&docid=100708\&pageIn$\mathrm{dex}=0 \&$ doclang $=$ en \&mode $=1$ st\&dir=\&occ=first\&part=1\&cid=74816, 01 June 2018.

${ }^{39}$ Para. 26. of the Judgement.

${ }^{40}$ Para. 27. of the Judgement. 
EU law, although it is evident that it contains subjective elements and that it is not based on an objective test, but on a test of reasonable behaviour of the producers of the same type of product. By allowing such a provision to exist and have legal force, the Court has, despite adhering to the principle and clear definition of an objective test in the application of the institution of development risks, and therefore the objective character of the producer's liability, left open the possibility of introducing subjective elements into the institute of objective producer's liability. In this respect, it can be said that the Court left room for various interpretations of Art. 7. para. 1. point (e) of the Directive, as well as those which are extensive and subjective. ${ }^{41}$

The proclaimed objectivity of the criteria in the assessment of development risks was disrupted by the Court deciding on another problem, the accessibility of knowledge. Namely, the Court concludes that "the relevant scientific and technical knowledge must have been accessible at the time when the product in question was put into circulation" 42 , without further elaboration on what the accessibility of knowledge implies. ${ }^{43}$ Now speaking of the accessible knowledge, the Court has deviated from the previously set overall knowledge, limiting relevant knowledge to only what was available to the producer at the time of placing the product on the market. Such a conclusion of the Court means that the producer, from, for example the United Kingdom may be relieved of liability if he proves that a particular research has been carried out in, for example, Japan, but that it was simply not available because the results of the research were not published anywhere in English, but only in Japanese in a scientific journal published only in Japan and not available in the United Kingdom. By linking the concept of accessibility with scientific and technical knowledge, the Court actually allows the producer to prove that he is not guilty of damages because certain knowledge was not available to him. Thus, the Court also allowed the penetration of subjective elements into the objective liability of the producer, which would now remain purely objective only if every information was relevant and represented scientific and technological knowledge, irrespective of the place in the world and the language it was published in. ${ }^{44}$

${ }^{41}$ Some authors consider that Art. 7. para. 1. point (g) of the Directive should be interpreted extensively and subjectively, because a strict and objective interpretation of this article makes the defence of the producer by referring to development risks practically impossible, that is, a producer with such a defence would almost never be successful when it would suffice that anywhere in the world there is a research, the existence of which he was unfamiliar with. Therefore, these authors advocate the introduction of a criterion of reasonable behaviour by the manufacturer. For more on this see: S. Petrić, M. Bukovac Puvača, pp. 217-218.

${ }^{42}$ Para. 28. of the Judgement.

${ }^{43}$ See: C. Hodges, pp. 563-564.

${ }^{44}$ See: S. Petrić, M. Bukovac Puvača, p. 222. 
In this manner, despite the fact that certain issues of development risks have been clarified, the Court has further stirred up theoretical debates over whether this exculpatory reason led to the change in the objective nature of the liability of the manufacturer of a defective product. ${ }^{45}$

\section{ADVANTAGES AND DISADVANTAGES OF DEVELOPMENT RISKS}

The dispute over the need for existence of development risks as the basis for the relief of the producer of the liability dates from the time of the adoption of the Directive, this issue remaining a current issue to this date. We saw that Finland and Luxembourg did not want to implement the provision of Art. 7. para. 1. point (e) of the Directive into their domestic law, and we also noted that Austria, Spain, Germany and France have envisaged significant restrictions. This creates the need to consider in detail the advantages and disadvantages of development risk institutions.

Scientific and technical advances represent key arguments for the existence of development risks as the basis for the exemption of the producer from liability. There is no such progress without sophisticated and pioneering research, and they are carried out by producers. If the producer were to be responsible for development risks, then it would not be worthwhile for him to carry out such research. Rather than risking with a potentially troublesome product that could cause damage in the future, when science and technology reach a certain standard sufficient to detect the shortcoming, it would be better for a producer to opt for a safer solution, that is, a product that is less advanced, but for which at least it is certain it's completely safe. With such reasoning, science and technology would stagnate, the number of innovations would plummet, and the end cost would fall on the backs of the consumers and society as a whole. The institution of development risks releases the producers of the mentioned pressure, which leads to the advancement of science and technology, from which everyone benefits. Then, an additional "pro" argument is that it would be difficult for producers to obtain insurance against liability for undetectable defects without the existence of development risks, and the lack of such insurance would lead to an increase in the price of products, etc.

The basic argument against the existence of development risks as the basis for relieving the producer from liability is of a theoretical nature because it is assumed that the existence of this exculpatory reason with certain subjective elements

${ }^{45}$ In addition, the Court did not provide answer to a number of questions, such as the concepts of accepted scientific and technical knowledge, the concept of availability, etc. Cited in line with: P. Đundić, p. 468. 
undermines the coherence of the system of objective liability of the producers of defective products. It also suggests that it is not fair for consumers to bear the risk of dangerous activities from which the benefit is foremost enjoyed by producers, etc. ${ }^{46}$

Weighing arguments for and against is important when a state is determining whether or not to implement in its legal system the provision of Art. 7. para. 1. point (e) of the Directive. Furthermore, the EU itself wanted to examine the economic effects of the institution of development risks, so it hired the Roseli Foundation (Fondazione Rosselli), which presented the results in its report. ${ }^{47}$

\section{LACK OF DEVELOPMENT RISKS RULE IN THE SERBIAN LEGISLATION}

Serbian law does not contain the rules on development risks. The ZOO envisages only the general basis for relieving liability in the form of force majeure and actions of the injured party and third parties that have the character of force majeure..$^{48}$ This is not surprising, since the $\mathrm{ZOO}$ is a regulation that came into force before the Directive was adopted, and as we have already seen it represents a regulation that has hardly any rules prescribing the liability of producer for defective things. Simply put, development risks were not so actual at the time of the adoption of the $\mathrm{ZOO}$ and the lawmaker of that time did not see the need to enlist them among the exculpatory reasons. Similarly, the ZZP failed to include development risks among the grounds for relieving the producer of liability, even though it envisaged all others listed in the Directive. ${ }^{49}$

Accordingly, Serbian law is among the few in Europe, which does not allow producer to be relieved of liability on the basis of undiscoverable defects. When adopting the ZPP, the opportunity for more serious expert discussion on this matter was missed, and it is obvious that the Serbian legislature does not want to abandon the path which the $\mathrm{ZOO}$ has laid out, as the basic law regulating the obligation relationships in general, as well as torts law, although developmental risks by their nature represent something that is a specialty of consumer rights and as an exculpatory reason, they could have been introduced into Serbian legal systems with this special piece of legislation.

\footnotetext{
${ }^{46}$ For more reasons pro and contra the institute of development risks, as well as other arguments, see: M. Karanikić (2005), pp. 181-186.

${ }^{47}$ Analysis of the Economic Impact of the Development Risk Clause as provided by Directive 85/374/EEC on Liability for Defective Products, Final Report, www.europa.eu.int, 01 June 2018.

${ }^{48}$ Art. 177. of the ZOO.

${ }^{49}$ Art. 62. of the ZZP.
} 
So far, there are no signs that rule on development risks will be implemented even in the expected Serbian Građanski zakonik ${ }^{50}$ (Civil Code, hereinafter periodically also abbreviated as the GZ) which should be adopted in close future. Such rule did not find its place in the Prednacrt Građanskog zakonika ${ }^{51}$ (First Draft of Civil Code).

There are many reasons for including developmental risks to the list of grounds for relieving the producer of liability. Beside those above stated, in the context of Serbia, it should be added that this would ease the position of the importers of foreign products. Namely, most of the sophisticated and advanced products were not produced in Serbia, but imported from abroad, largely from EU Member States. When such a product inflicts damage, it's importer to Serbia is liable for it, whilst he could not be regressed against the EU producer, unless the producer comes from Finland or Luxembourg, where the same legal regime as in Serbia applies. Therefore, the existing legislative solution greatly aggravates the position of the importer of products from abroad, ${ }^{52}$ which should be taken into account when talking about the development risks.

As already mentioned, most of the products where the undiscoverable defects may arise are being imported to Serbia. At first sight, this can be an argument that points to the needlessness of undiscoverable risks as an exculpatory ground, because in practice they would have a small, if not insignificant, applicability. However, this viewpoint is not far-reaching. The raison d'etre of the institution of development risk is, inter alia, to encourage innovation, pioneering research and the development of science and technology. It cannot be ruled out that this institution in Serbian law could encourage producers to risk in the production of advanced products, and if nothing else, there would not be a legislative conundrum in that sense.

\section{CONCLUSION}

From everything above stated, it is clear that there are still many perplexities regarding developmental risks, both in legal theory and in case-law. It is not even universally clear whether development risks should exist as a basis for relieving the producer of liability. Their inclusion in the list of exculpatory grounds deviates from the principle of a complete consumer protection, which is among the fundaments of consumer law. However, if we see the advantage of this insti-

${ }^{50}$ Serbia is still waiting its modern GZ. It's drafting is very slow process and it started back in year 2006. For more on this see: Dušan Nikolić, Uvod u sistem građanskog prava (Introduction to System of Civil Law), Novi Sad 2016, p. 101.

${ }^{51}$ https://www.mpravde.gov.rs/files/NACRT.pdf, 01 June 2018.

${ }^{52}$ See: M. Karanikić (2005), pp. 190-192. 
tution in terms of encouraging innovation and scientific and technical development, then it is clear that this exception is justified and that the consumers themselves ultimately benefit.

The basic critique directed toward developmental risks is that they, as a ground for exclusion from liability, distort the theoretically harmonized system of objective - strict liability of the defective product producer. This is true, but if the unknowable risks are defined in the way set out by the Directive, the introduction of subjective elements in the concept of objective liability remains limited. After all, purely theoretical considerations should not overgrow the logic behind individual forms of accountability nor the importance of the reasons supporting certain grounds for the release from liability, and so the fact that development risks in some way do disturb the existing coherence of the objective liability of the defective product producer should not be more important than the advantages that development risks bring. In the specific case, with the acceptance of the developmental risks as defined by the Directive, as well as accepting for the limits of scientific and technical knowledge to be limited to that available to the producer, the system of objective liability for the defective products would undergo changes only by introduction of a subjective criteria test to determine which knowledge was available to the producer at the time of placing the product on the market. In all the rest, the rules of objective liability would remain applicable.

Serbia, which aspires to become an EU Member State, has to focus on the harmonization of its legal system with EU regulations, and thus also the harmonization with the Directive. It is obvious that is justified to implement rule on development risks in Serbian legislation because of all aforementioned advantages and benefits. The Directive, truth be told, does provide the possibility for Serbia to opt, as Finland and Luxembourg, for the exclusion of developmental risks from a list of exculpatory grounds, however, there seems to be no convincing reason for such a thing. If nothing else, Serbia may limit the scope of development risks in the same manner as it has been done in Spain, Austria, Germany and France, and there is also a possibility of establishing special funds that would be used to compensate consumers for damages suffered. Such means might minimize the negative consequences of the introduction of development risks in the Serbian legal system. 


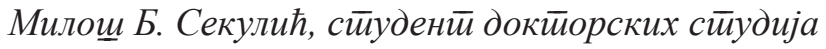
Универзииетеи у Новом Саду

Правни факулиетеи у Новом Саду

milossekulic89@gmail.com

\section{Развојни ризици - одређење у праву Европске уније и оправданост имплементације у српско право}

Сажейак: У раду се анализира једно од најважнијих и најакӣуелних иичйања у вези са одг̄оворнощћу ирроизвођача ироизвода са недоститиаком, будући да овај облик одг̄оворностии развојем йоирощачког̄ ирава добија све већи значај, ири чему је акценай на развојним ризицима као једном од основа за екскулйаиију йроизвођача као одг̄оворног лиия. Након краћег̄ ирредстиављаґа одг̄оворностии йроизвођача йроизвода са недосийиаком, фокус рада се ирребаиује на устианову развојних ризика која је ириказана најйре са асиеккйа

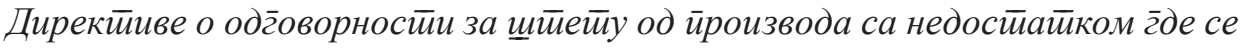

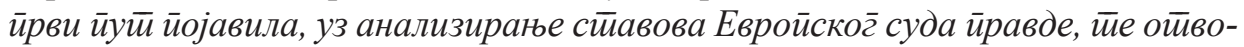
рених ироблема које она са собом носи, као и уочавања юених ирредностии и мана. На крају рада, размйара се да ли развојни ризици мењају йравну йрироду одг̄оворносиии ирроизвођача, односно да ли доводе до йродора субјек-

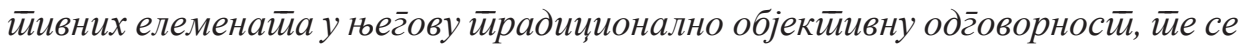

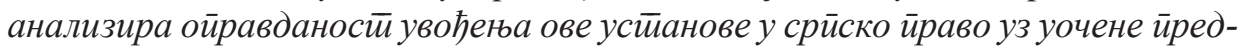
ностии и мане.

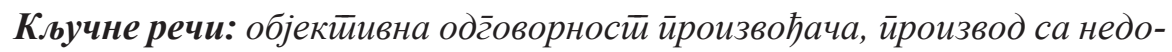

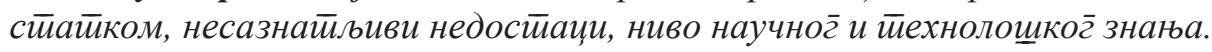

Датум пријема рада: 22.06.2018. 